\title{
Peningkatan Daya Saing Siswa Menengah Kejuruan Swasta melalui Pelatihan Regulasi Diri
}

\author{
Hastaning Sakti ${ }^{1}$, Jati Ariati ${ }^{2}$ \\ Fakultas Psikologi Universitas Diponegoro
}

\begin{abstract}
The aim of this research was to design self-regulation training as an alternative effort to enhance students' competitiveness. A total number of 147 students from two private vocational schools were involved as subjects. Pretest posttest control group design was used. In each school there were an experimental group, which got self-regulation training, and a control group, which got self-concept training. Manipulation was delivered six times each of which was supervised by two observers. T-test showed there were differences between experimental groups. SMK PL: before $(\mathrm{M}=89.93, \mathrm{SD}=7.681)$ and after manipulation $(\mathrm{M}=92.16$, $\mathrm{SD}=7.278) t(43)=-2.185, p<.05$. SMK TU: before $(\mathrm{M}=90.62, \mathrm{SD}=7.206)$ and after manipulation $(\mathrm{M}=94.03, \mathrm{SD}=7.962) t(31)=-2.381, p<.05$ and also control groups of two schools showed the same data. However, there were no differences in the competitiveness between experiment groups and control groups.
\end{abstract}

Keywords: self regulation, competitiveness, vocational school, randomized pre-test post-test control group design

\begin{abstract}
Abstrak. Tujuan dari penelitian ini adalah mendesain pelatihan regulasi diri sebagai usaha meningkatkan daya saing siswa. 147 siswa dari dua sekolah menengah kejuruan swasta menjadi subjek. Desain penelitian menggunakan pre test-post test control group design dengan di setiap sekolah terdiri dari kelompok eksperimen (mendapat pelatihan regulasi diri) dan kelompok kontrol (mendapat pelatihan konsep diri). Manipulasi dilakukan selama enam kali dengan kehadiran dua observer di setiap perlakuan. T-test menunjukkan bahwa ada perbedaan daya saing di setiap kelompok eksperimental SMK PL: sebelum (M=89.93, $\mathrm{SD}=7.681)$, sesudah $(\mathrm{M}=92.16, \mathrm{SD}=7.278) t(43)=-2.185, p<.05$. SMK TU: sebelum $(\mathrm{M}=90.62$, $\mathrm{SD}=7.206)$, sesudah $(\mathrm{M}=94.03, \mathrm{SD}=7.962) t(31)=-2.381, p<.05$, demikian juga di setiap kelompok kontrol. Namun tidak ada perbedaan daya saing antara kelompok eksperimen dan kelompok kontrol di setiap sekolah.

Kata kunci: regulasi diri, daya saing, sekolah menengah kejuruan, randomized pre-test post-test control group design
\end{abstract}

Griffin-Pierson (1990) mendefinisikan daya saing sebagai keinginan untuk menang dalam situasi interpersonal, sedangkan Ryckman, dkk (Houston, McIntire, Kinnie, \& Terry, 2002) mengemukakan bahwa daya saing adalah sikap menghargai kenikmatan dan proses dari tugas di

\footnotetext{
${ }^{1}$ Korespondensi mengenai isi artikel ini dapat dilakukan melalui: sakti.hasta@gmail.com

${ }^{2}$ Atau melalui: ariati.jati@undip.ac.id
}

luar kemenangan. Sementara, Brehn dan Kassin (Bernadin \& Russell, 1998) mengemukakan bahwa daya saing dibangun dari satu set keahlian dan kompentensi. Kompetensi direpresentasikan sebagai pengetahuan, keterampilan, dan kemampuan individu yang ditampilkan secara aktif.

Daya saing dibutuhkan dalam situasi persaingan. Persaingan menurut Brehn 
dan Kassin (1990) adalah suatu aktivitas atau usaha untuk melawan orang lain untuk kepentingan yang lebih besar dengan mengesampingkan orang lain. Baron dan Byrne (1991) mengemukakan bahwa persaingan adalah usaha keras dari setiap orang untuk memaksimalkan pendapatan sendiri, yang tak jarang mengorbankan pendapat orang lain.

Chickering (1993) mengembangkan tujuh vektor perkembangan meliputi: pengembangan kompetensi, manajemen emosi, pergerakan terus-menerus dari otonomi menuju interdependensi, pengembangan hubungan interpersonal yang matang, penetapan identitas, pengembangan tujuan, dan pengembangan integritas. Tujuh vektor yang masing-masing dilihat sebagai aspek spesifik dari konsep sentral "identitas" ini, dikembangkan berdasarkan teori dari Erikson.

\section{Aspek-aspek Daya Saing}

Aspek-aspek daya saing diambil dari tujuh vektor menurut Chickering dan Reisser (1993) serta Chickering dan Schlossberg (1995): (1) pengembangan kompetensi, kompentensi terdiri dari kompetensi intelektual, kompetensi fisik dan manual, dan kompetensi interpersonal; kompetensi intelektual mencakup penggunaan kemampuan berpikir untuk memahami, membayangkan, analisis, sintesis, dan interpretasi; kompetensi fisik dan manual mencakup penggunaan tubuh sebagai sarana kesehatan untuk performansi yang tinggi, ekspresi diri, dan kreativitas; kompetensi interpersonal adalah kemampuan untuk berkomunikasi dan berkolaborasi dengan orang lain; (2) manajemen emosi, manajemen emosi diawali dengan lebih menyadari perasaan, kemudian mempelajari kontrol yang fleksibel dan makna yang cocok dari ekspresi, selain itu juga diperlukan penemuan cara untuk menyeimbangkan perasaan negatif dan perasaan positif, dan mengintegrasikan perasaan dengan pikiran dan perbuatan; (3) pergerakan terus-menerus dari otonomi menuju interdependensi, aspek ini meliputi tiga komponen, yaitu independensi emosional, independensi instrumental, interdependensi; independensi emosional berarti bebas dari kebutuhan yang terus-menerus dan menekan penentraman hati, kasih sayang, dan persetujuan dari orang lain; independensi instrumental berarti kemampuan melakukan aktivitas dan pemecahan masalah dalam pengaturan diri, serta bebas dan percaya secara aktif untuk mengejar kesempatan dan petualangan; interdependensi berarti sebuah kesadaran akan kedudukan seseorang dan komitmen untuk menyejahterakan komunitas yang lebih luas; (4) pengembangan hubungan interpersonal yang matang, pengembangan hubungan interpersonal yang matang terdiri dari dua komponen, yaitu toleransi dan respek terhadap perbedaan, dan kapasitas intimasi; keduanya memerlukan kemampuan untuk menerima individu sebagaimana adanya, menghargai dan menerima perbedaan, dan berempati; toleransi membutuhkan kemauan untuk menunda pendapat, menahan diri dari penghakiman, dan berusaha memahami cara berpikir atau tindakan yang tidak biasa atau mengganggu daripada mengabaikan, menyerang atau meremehkannya; meningkatkan kapasitas intimasi memerlukan perubahan kualitas hubungan dengan pasangan dan teman dekat; (5) penetapan identitas; penetapan identitas melibatkan pertumbuhan kesadaran akan kompetensi, emosi, nilai-nilai, kepercayaan untuk berdiri sendiri dan terikat dengan orang lain, dan bergerak dari ketidaktoleransian menuju keterbukaan dan harga diri; (6) pengembangan tujuan, pengembangan tujuan memerlukan perumusan rencana tindakan 
dan sekumpulan prioritas yang terintegrasi dalam tiga elemen utama, yaitu rencana dan aspirasi vokasional, minat pribadi, serta komitmen interpersonal dan keluarga; pengembangan tujuan juga meliputi peningkatan yang bertujuan untuk latihan pribadi dalam dasar sehari-hari, yaitu menjadi terampil dalam memilih prioritas secara sadar, dalam menyejajarkan tindakan dengan tujuan, dalam memotivasi diri sendiri ke arah tujuan secara konsisten, dan tekun meskipun terhalang atau mengalami kemunduran; (7) pengembangan integritas, pengembangan integritas melibatkan peninjauan kembali nilai-nilai pribadi dalam lingkungan menekankan pada perbedaan, pemikiran kritis, serta manfaat dari fakta-fakta dan percobaan; pengembangan integritas memerlukan tiga rangkaian yang saling melengkapi, yaitu menentukan nilai-nilai humanis, menentukan nilai-nilai personal, dan mengembangkan kongruensi; menentukan nilai-nilai humanis berarti perubahan dari aplikasi otomatis kepercayaan yang dipegang teguh dan menggunakan dasar pemikiran dalam menyeimbangkan kepentingan diri sendiri dengan seseorang sebagai sesama manusia; menentukan nilai-nilai personal berarti secara sadar menegaskan nilai-nilai dan kepercayaan inti dengan menghargai sudut pandang orang lain; mengembangkan kongruensi berarti mencocokkan nilainilai personal dengan tingkah laku yang bertanggung jawab secara sosial.

Faktor-faktor yang Mempengaruhi Daya Saing

Menurut Chickering dan Reisser (1993), delapan kunci yang mempengaruhi daya saing adalah (1)tujuan institusional yang jelas dan konsisten; tujuan yang jelas juga membuat anggota organisasi dapat melakukan sesuatu secara individual dengan lebih kongruen satu sama lain, membuat anggotanya dapat menyesuai- kan diri secara sadar, misalnya koreksi diri, sehingga memberi kesempatan untuk melakukan modifikasi perilaku; (2) ukuran institusional, ukuran institusional yang kecil, merupakan salah satu hal yang dibutuhkan untuk membuat tujuan yang jelas. Jumlah orang yang sedikit membuat masing-masing orang memiliki kesempatan yang lebih banyak untuk berpartisipasi dan memperoleh lebih banyak kepuasan dari pengalaman; (3) hubungan siswasekolah, hubungan dengan pihak sekolah merupakan hubungan yang paling penting bagi siswa setelah hubungan dengan teman sebaya, pengaruh dari interaksi interpersonal dengan kelompok, ditunjukkan melalui hasil intelektual, baik dalam perubahan sikap, nilai-nilai, aspirasi, maupun sejumlah karakteristik psikososial; (4) kurikulum, kurikulum, seharusnya menjadi pemikiran yang memasukkan semua aktivitas dan investasi yang bermacammacam, yaitu pengalaman seorang siswa tentang sekolah, kurikulum merupakan rangkaian mata pelajaran yang ditawarkan oleh sebuah institusi pendidikan, sekolah menyediakan baik pendidikan budaya maupun pendidikan profesional atau vokasional, perbedaan yang kritis perlu dibuat antara untuk bekerja dan persiapan untuk sebuah pekerjaan; (5) pengajaran, istilah "pengajaran" dibatasi pada aktivitas yang secara langsung berhubungan dengan program akademik dan dilakukan oleh anggota sekolah, konsekuensi potensial pengajaran pada perkembangan siswa akan sangat besar, jika seseorang guru menjadi pengajar yang efektif, proses belajar siswa sudah terhubung secara jelas dengan pengajaran yang efektif, sejumlah tingkah laku pengajar diasosiasikan secara positif dengan pengetahuan siswa, dan dua yang terpenting adalah keterampilan mengajar (terutama kejelasan presentasi) dan menyusun pelajaran; (6) persahabatan dan komunitas siswa, guru yang paling 
penting bagi seorang siswa seringkali adalah siswa lainnya, persahabatan yang didasarkan pada kejujuran dan empati membawa penerimaan, kegembiraan, dan loyalitas; (7) program dan pelayanan pengembangan siswa, profesi pengembangan siswa didefinisikan sebagai pekerjaan yang berdasarkan pada perhatian pada semua aspek dari pengalaman siswa, profesi pengembangan siswa mencakup filosofi holistik dan teori serta penelitian perkembangan siswa, meskipun cenderung dikhususkan pada fungsi administratif, penting bagi staf pengembangan siswa untuk tidak melupakan tanggung jawab sebagai pendukung pendidikan dari seluruh mahasiswa; (8) lingkungan yang kuat dalam pendidikan, sekolah harus berubah, melakukan pembaharuan, tugas paling kritis adalah menciptakan lingkungan yang kuat dalam pendidikan, yang berarti lingkungan dapat meningkatkan perkembangan mahasiswa. Karakteristik latar belakang siswa dalam perkembangan siswa penting untuk diperhatikan. Keluarga mungkin menawarkan pertentangan yang aktif atau pasif, dan pengalaman awal tentang kegagalan atau harga diri yang rendah, yang mungkin menyebabkan ambivalensi atau kecemasan. Orientasi positif dapat menjadi sumber dukungan bagi siswa untuk menghadapi tantangan.

Lembaga pendidikan formal bukan hanya bertugas sebagai wadah untuk transfer of knowledge, melainkan juga sebagai cara untuk turut membentuk karakter positif. Banyak peserta didik yang kurang berhasil dalam capaian prestasi akademik bahkan mengalami kegagalan dikarenakan tidak atau kurang memiliki karakter dan sifat yang positif sehingga mereka tidak dapat memanfaatkan lingkungan akademik secara maksimal meskipun secara intelektual termasuk siswa yang unggul
(Sawitri \& Ariati, 2010).

Lebih lanjut, ditemukan dalam hasil survey yang dilakukan oleh Yayasan Kesejahteraan Anak Indonesia terhadap 306 orang siswa kelas 4-6 tahun 1997 menunjukkan rata-rata anak menonton televisi sekitar $26 \mathrm{jam} /$ minggu yang kemudian meningkat menjadi 35 jam/minggu pada tahun 2001. Sebanyak 50\% responden menyadari bahwa mereka terlalu lama di depan televisi sehingga cenderung lupa untuk belajar (http://suaragratiafm. wordpress.com). Selain itu dari data yang didapatkan dari sepuluh kota besar di Indonesia menunjukkan bahwa anak-anak usia 10-14 tahun menghabiskan waktu menonton televise selama 4,2 jam (2000), meningkat menjadi 4,6 jam (2005) dan menjadi 4,4 jam pada 2010 (Hendriyani \& Guntarto, 2011). Ketidakmampuan anak dalam mengatur jadwal belajar dengan bermain (merupakan salah satu kemampuan dalam self regulation academic) membuat proses belajar menjadi terabaikan. Hasil pencapaian akademik yang tidak maksimal dikarenakan proses belajar yang kurang optimal menyebabkan siswa memandang rendah diri mereka dan mempengaruhi efikasi diri secara umum (Diseth, 2011).

Self regulated learning berkaitan dengan kemampuan regulasi diri dalam belajar di sekolah (Printich, 2000). Self regulated learning telah menjadi sebuah konstruk yang sangat penting dalam dunia pendidikan (Boekaerts, 1999). Bandura (Woolfolk, 2010) meringkas regulasi diri sebagai penetapan tujuan serta perjalanan usaha dan sumber yang diperlukan untuk mencapai tujuan. Secara umum, siswa dapat dikatakan telah mampu meregulasi dirinya apabila ia telah mampu aktif secara metakognitif, motivasi, dan perilaku sehingga tidak bergantung pada orang lain di sekitarnya. Dengan kata lain siswa 
mampu untuk secara proaktif memilih, mengatur, dan menciptakan lingkungan belajar yang menguntungkan dan dapat berperan secara signifikan (Zimmerman, 2001). Siswa dengan self regulated learning tidak hanya sukses secara akademik tetapi juga akan memandang masa depan dengan lebih optimis (Boekaerts \& Niemivierta, 2000).

Self regulated learning memiliki aspekaspek sebagai berikut: (1) metakognisi, yaitu kesadaran siswa tentang kekuatan dan kelemahan akademik, sumber kognitif yang dapat diterapkan untuk memenuhi tuntutan tugas tertentu, dan pengetahuan tentang pengaturan keterlibatan diri dalam tugas-tugas untuk mengoptimalkan proses dan hasil belajar, dalam aspek ini, siswa merencanakan, membuat tujuan belajar, mengorganisasi, memonitor diri, dan mengevaluasi diri dalam proses belajar, (2) motivasi, yaitu keyakinan siswa dalam belajar. Siswa yang termotivasi adalah yang memiliki keinginan pribadi untuk maju dan memahami materi secara mendalam, dan (3) perilaku, dalam aspek ini siswa memilih, menyusun, dan membentuk lingkungan untuk dapat optimal dalam belajar.

Self regulated learning dipengaruhi oleh faktor pribadi yang mencakup efikasi diri dalam belajar untuk mencapai tujuan belajar dan faktor lingkungan. Kedua faktor ini saling memberikan pengaruh timbal balik terhadap individu. Inisiatif siswa akan mengubah lingkungan sosial dan fisik yang kemudia siswa akan dipengaruhi oleh perubahan ini. Siswa yang tidak menggunakan sumberdaya lingkungan fisik dan sosial atau melihat kedua hal ini sebagai hambatan akan menjadi kurang efektif dalam mengatur kehidupan mereka (Schunk \& Ertmer, 2000; Zimmerman, 2000). Salah satu dari sumberdaya ling- kungan sosial adalah keluarga (orangtua) dan guru.

Ciri-ciri dari siswa yang telah menjadi self regulated learners adalah: (1) dapat meningkatkan kemampuan belajar dengan menggunakan strategi belajar metakognitif yang tepat, berupa mencatat materi pelajaran dengan bahasa sendiri, mengorganisasikan catatan materi pelajaran, memperluas pengetahuan, dan mengejar kembali ketertinggalan materi yang mungkin dialami, (2) proaktif memilih, mengatur, bahkan menciptakan lingkungan belajar yang menguntungkan dengan merencanakan dan mengontrol waktu serta usaha untuk mengerjakan tugas, tahu bagaimana menciptakan dan mengatur lingkungan belajar yang menyenangkan, (3) dapat memainkan peran yang signifikan dalam memilih bentuk dan banyaknya pelajaran yang mereka butuhkan, (4) siswa mengerti bagaimana merencanakan, mengontrol, dan mengatur proses mental dalam rangka mencapai tujuan pribadi, (5) siswa memiliki keyakinan motivasi dan emosi adaptif, seperti efikasi diri akademik yang tinggi, penggunaan tujuan belajar, mengembangkan emosi positif terhadap tugas, dan (6) siswa mampu menggunakan strategi, menghindari gangguan eksternal dan internal dalam rangka untuk menjaga konsentrasi, usaha, dan motivasinya ketika melaksanakan tugas akademik (Zimmerman, 2002; Montalvo \& Torres, 2004).

Didasarkan pada paparan teoritis di atas dapat dilihat pengaruh atau hasil yang mungkin didapatkan apabila seorang siswa menjadi seorang self regulated learner, yaitu keberhasilan dalam bidang akademik yang ditunjang dengan kemampuan untuk memanfaatkan, mengorganisasi, dan mengontrol lingkungan fisik dan sosialnya secara efektif. Dapat disimpulkan meskipun seorang siswa memiliki 
tingkat inteligensi yang baik, kepribadian, lingkungan rumah dan sekolah yang mendukungnya, namun tanpa ditunjang oleh kemampuan regulasi diri maka siswa tersebut tetap tidak akan mampu mencapai prestasi optimal. Dengan kata lain, siswa yang memiliki regulasi diri dalam belajar membuat ia mencapai level efikasi diri akademik yang lebih tinggi dan berimbas pada prestasi akademik yang lebih baik pula (Labuhn, Zimmerman, \& Hasselhorn, 2010). Regulasi diri merupakan kompetensi kunci yang menentukan kesuksesan seorang siswa (Panadero, Tapia, \& Huertas, 2012). Prestasi akademik yang baik merupakan salah satu indikator bahwa siswa memiliki daya saing yang baik pula, meskipun nilai bukan merupakan satu-satunya yang menentukan, karena siswa dengan penguasaan materi juga penting (Diseth, 2011).

Penelitian yang terkait dengan studi tentang regulasi diri dilakukan dalam konteks budaya individualis dan kolektif. Di Korea, keberhasilan anak-anak dalam dunia pendidikan, karena mereka melibatkan ibu sebagai mediator antara lingkungan eksternal dengan siswa sebagai pribadi. Hubungan yang dekat dengan orangtua menyebabkan siswa mampu menyikapi tugas-tugas belajarnya secara positif. Dengan kata lain, ada peran yang besar dari orangtua untuk kesuksesan anaknya. Penelitian ini dilakukan dengan menggunakan pendekatan kuantitatif (open ended questionaire) dan kualitatif yaitu dengan teknik FGD (Park \& Kim, 2006).

Terkait dengan hubungan antara orangtua-anak ini, ada penelitian lain dengan metode kuantitatif juga yang menyebutkan bahwa kepatuhan dan konflik yang terjadi antara orangtua dan anak akan mempengaruhi motivasi anak-anak untuk belajar. Dengan kata lain ada pengaruh dari tekanan akademis dari orang tua, dukungan, dan hubungan yang dipersepsikan oleh siswa yang akan mempengaruhi strategi belajar yang dipilih (Bong, 2008).

Hasil penelitian lain menyebutkan, bahwa ketika siswa tidak memiliki kemampuan regulasi diri ia cenderung melakukan prokrastinasi akademik, yaitu penundaan penyelesaian tugas-tugas akademik, sehingga pencapaian akademiknya menjadi tidak optimal dikarenakan perila$\mathrm{ku}$ akademik yang maladaptif yang bahkan juga terjadi pada tingkat pendidikan tinggi (Wolters, 2003). Siswa seperti ini dikatakan tidak memiliki motivasi intrinsik untuk mencapai keberhasilan dalam bidang akademik. Sebaliknya siswa dapat menjadi seorang self regulated learner dikarenakan ia memiliki minat (motivasi) sehingga ia dapat menetapkan strategi yang tepat (Soric \& Palekcic, 2009; Rakes, 2010).

Secara singkat, didasarkan pada paparan teoritis di atas, maka hipotesis yang diajukan dalam penelitian ini adalah: ada perbedaan daya saing sebelum dan sesudah perlakuan pada kelompok eksperimen.

\section{Metode}

Penelitian ini menggunakan pendekatan eksperimental dengan pretest-posttest control group design. Pretest dan posttest menggunakan skala daya saing yang terdiri dari 30 aitem $(\alpha=.88)$. Skala daya saing disusun menggunakan skala likert yang terdiri dari empat pilihan jawaban mulai dari nilai 1 (sangat tidak sesuai) dan nilai 4 (sangat sesuai) untuk aitem favorable dan sebaliknya. Contoh aitem unfavorable adalah: "Saya mudah putus asa saat menemui kesulitan dalam mengerjakan tugas sekolah". Analisis data menggunakan Ttest. Penelitian dilakukan di dua SMK 
swasta yaitu SMK 'PL' dan SMK 'TU'. Berikut daftar kelas yang terlibat dalam penelitian ini:

\section{Tabel 1}

Daftar Subjek Penelitian

\begin{tabular}{llcc}
\hline Sekolah & Kelas & Jumlah Siswa & Posisi \\
\hline SMK PL & X MM 1 & 45 & KE \\
& X AP 1 & 42 & KK \\
SMK TU & X PM 1 & 33 & KE \\
& X AK 1 & 30 & KK \\
\hline
\end{tabular}

Keterangan:

KE : Kelompok Eksperimen

AP : Akuntansi Perkantoran

KK : Kelompok Kontrol

PM : Pemasaran

MM : Manajemen

AK : Akuntansi

Penerapan modul pembelajaran diawali dari pemilihan kelompok kontrol dan kelompok eksperimen. Kelompok eksperimen adalah kelompok yang mendapat perlakuan, yaitu pelatihan regulasi diri. Kelompok kontrol adalah kelompok yang mendapat placebo yaitu pelatihan konsep diri. Modul pelatihan regulasi diri terdiri dari: penetapan tujuan, manajemen emosi, manajemen waktu, manajemen lingkungan fisik, dan manajemen lingkungan sosial. Modul konsep diri terdiri dari: who am I, evaluasi diri, motivasi diri, sungai kehidupan, dan berpikir positif.

Validitas internal dari modul yang disusun diwujudkan melalui professional judgement yang dilakukan oleh trainer yang telah berpengalaman dalam bidang psikologi pendidikan dan tryout pada sekolah kejuruan swasta lainnya yang memiliki siswa bermasalah, di mana dalam setiap pelaksanaan materi dihadiri oleh dua observer yang memastikan cakupan materi dan pencapaian tujuan dalam setiap sesi.

Kelompok eksperimen terdiri dari dua kelas yaitu di SMK PL dan SMK TU. Demikian pula halnya dengan kelompok eksperimen. Pertimbangan pemilihan kelas di antara kedua kelas tersebut untuk menjadi kelompok eksperimen dan kelompok kontrol dilakukan secara random dengan membuat undian. Namun demikian karena undian tidak dibuat dengan melibatkan seluruh kelas yang ada pemilihan kelompok ini dapat dikategorikan sebagai nonrandom assignment. Bagan alur pelaksanaan pelatihan terlihat pada Gambar 1.

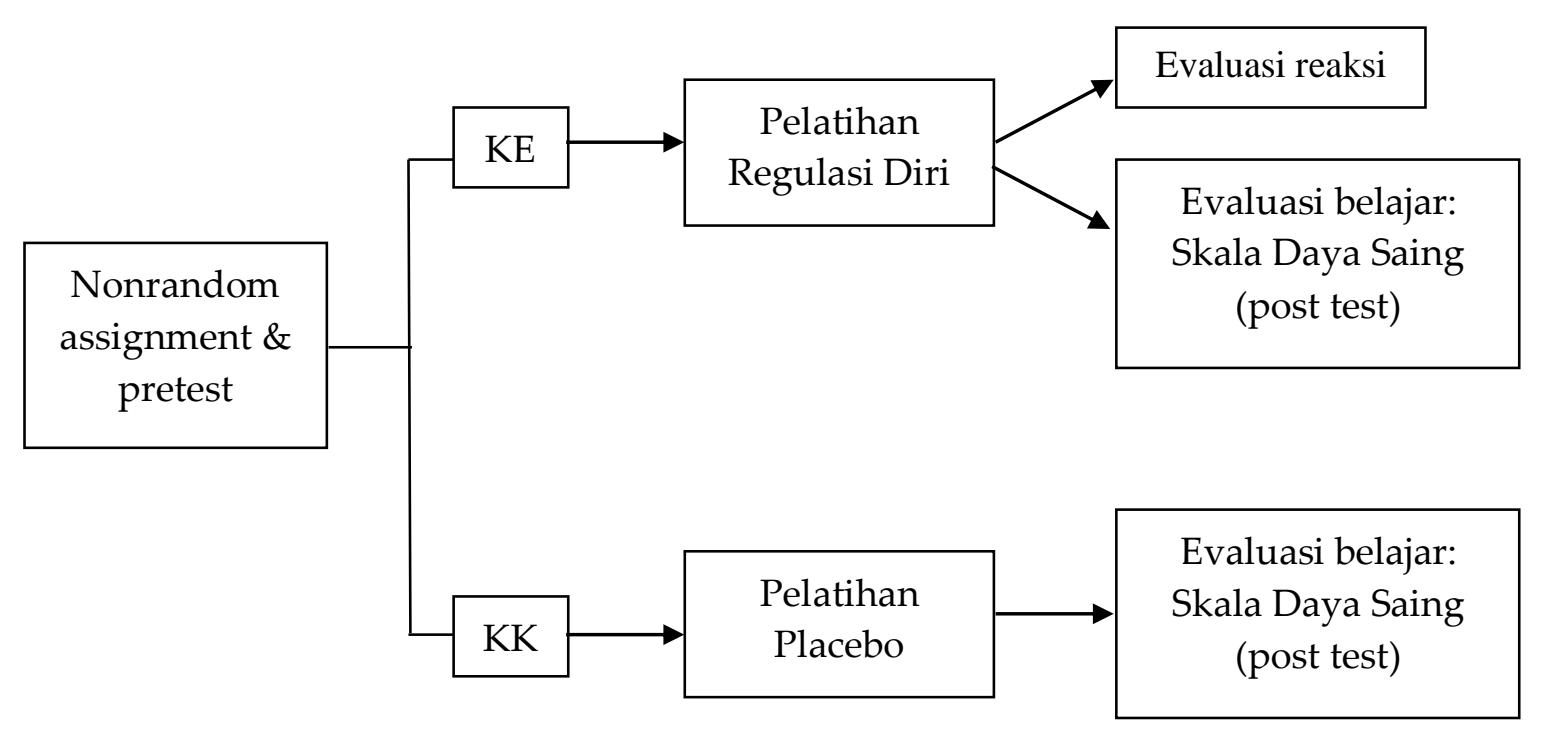

Gambar 1. Alur pelaksanaan pelatihan 
Pelatihan regulasi diri dan pelatihan konsep diri masing-masing dilakukan dalam enam kali tatap muka dengan jeda 2-3 hari antar tatap muka. Selama pelatihan berlangsung, di setiap kelas hadir dua orang observer untuk bersepakat (interobservers agreement) terhadap setiap materi dan komponen yang harus ada di masing-masing pelatihan didasarkan pada modul yang telah disusun dan menuliskannya dalam bentuk ceklis observasi.

\section{H a s i 1}

Terpenuhinya uji asumsi normalitas pada seluruh kelompok data $(z<1,97)$, mendorong digunakannya uji $t$ untuk menganalisis data. Berikut hasil lengkap dari data kelompok eksperimen dan kontrol pada kedua sekolah:
Hasil pengujian hipotesis menunjukkan adanya peningkatan daya saing sebelum dan sesudah perlakuan pada kelompok eksperimen. Pada SMK PL, daya saing sesudah $(\mathrm{M}=92.16, \quad \mathrm{SD}=7.28)$ berbeda secara signifikan dibanding dengan daya saing sebelum $(\mathrm{M}=89,93, \mathrm{SD}=7,68), t(43)=$ $-2,18, p<.05$. Kondisi serupa juga diikuti di SMK TU. Daya saing sesudah $(\mathrm{M}=94.03$, $\mathrm{SD}=7.96)$ berbeda secara signifikan dibanding dengan daya saing sebelum $(\mathrm{M}=90,62, \quad \mathrm{SD}=7,21), \quad t(31)=-2,38, \quad p<.05$. Demikian pula pada kelompok kontrol di kedua sekolah. Pada SMK PL, daya saing sesudah $(\mathrm{M}=90,8, \mathrm{SD}=7.47)$ berbeda secara signifikan dibanding dengan daya saing sebelum $(M=90,55, S D=7,30), t(40)=-2,98$, $p<.05$, sedangkan pada SMK TU, daya saing sesudah $(M=92,93, S D=6,43)$ berbeda secara signifikan dibanding dengan daya saing sebelum $(\mathrm{M}=94,03, \mathrm{SD}=7,96), t(29)=$

Tabel 2

Analisis Paired T-test

\begin{tabular}{|c|c|c|c|c|c|c|c|c|}
\hline \multirow{3}{*}{ Sekolah } & \multirow{3}{*}{$\mathbf{N}$} & \multicolumn{4}{|c|}{ Kelompok Eksperimen } & \multirow{3}{*}{$\mathbf{t}$} & \multirow{3}{*}{ df } & \multirow{3}{*}{ Sig } \\
\hline & & \multicolumn{2}{|c|}{ Pre-test } & \multicolumn{2}{|c|}{ Post test } & & & \\
\hline & & $\mathbf{M}$ & SD & $\mathbf{M}$ & SD & & & \\
\hline SMK PL & 44 & 89.93 & 7.681 & 92.16 & 7.278 & -2.185 & 43 & .034 \\
\hline SMK TU & 32 & 90.62 & 7.206 & 94.03 & 7.962 & -2.381 & 31 & .024 \\
\hline \multicolumn{9}{|c|}{ Kelompok Kontrol } \\
\hline SMK PL & 41 & 90.27 & 8.246 & 92.59 & 6.841 & -2.978 & 40 & .005 \\
\hline SMK TU & 30 & 88.87 & 6.285 & 92.93 & 6.427 & -2.520 & 29 & .018 \\
\hline
\end{tabular}

Tabel 3

Analisis Independent T-test

\begin{tabular}{|c|c|c|c|c|c|c|c|c|c|}
\hline \multirow{3}{*}{ Sekolah } & \multicolumn{6}{|c|}{ Pre-test } & \multirow{3}{*}{$\mathbf{t}$} & \multirow{3}{*}{ df } & \multirow{3}{*}{ Sig } \\
\hline & \multicolumn{3}{|c|}{ KE } & \multicolumn{3}{|c|}{ KK } & & & \\
\hline & $\mathbf{N}$ & $\mathbf{M}$ & SD & $\mathbf{N}$ & $\mathbf{M}$ & SD & & & \\
\hline SMK PL & 44 & 89.93 & 7.681 & 41 & 90.27 & 8.246 & -.195 & 83 & .846 \\
\hline SMK TU & 32 & 90.62 & 7.206 & 30 & 88.87 & 6.285 & 1.021 & 60 & .311 \\
\hline \multicolumn{10}{|c|}{ Post-test } \\
\hline SMK PL & 44 & 90.55 & 7.299 & 41 & 90.80 & 7.471 & -.162 & 83 & .872 \\
\hline SMK TU & 32 & 94.03 & 7.962 & 30 & 92.93 & 6.427 & .595 & 60 & .554 \\
\hline
\end{tabular}


$-2,52, p<.05$. Hasil ini berdampak pada daya saing di kelompok eksperimen dan kelompok kontrol pada dua sekolah, yaitu tidak ada perbedaan daya saing antara kelompok eksperimen dan kelompok kontrol setelah perlakuan. Secara singkat dapat disampaikan, hipotesis yang diajukan dalam penelitian ini dapat diterima.

\section{Diskusi}

Pelatihan regulasi diri merupakan salah satu upaya yang dapat ditempuh untuk meningkatkan daya saing siswa (Sawitri \& Ariati, 2011), bahkan pada siswa yang beresiko. Selama intervensi berlangsung, siswa memiliki motivational belief yang membantu mereka untuk meregulasi diri, misal siswa merasa bahwa pelatihan berjalan menarik, mereka membutuhkan pelatihan ini, dan kemudian saling membutuhkan satu sama lain, sehingga mereka bersedia untuk berkontribusi (Boekaerts, 2010). Vandevelde, Van Keer, dan de Wever (2011) juga menyampaikan, adanya bantuan dari teman sebaya, membuat siswa lebih bersemangat untuk terlibat dalam proses belajar. Ketika siswa merasa terlibat, maka ia akan berusaha optimal dalam mencapai tujuan yang ia tetapkan, dimana penetapan tujuan merupakan salah satu vektor dari daya saing.

Fakta yang menarik dari penelitian ini adalah tidak ada perbedaan daya saing dari kelompok eksperimen dan kelompok kontrol setelah perlakuan. Ada dua hal yang mempengaruhi hal ini. Pertama, kondisi ini disebabkan karena adanya konsep diri yang positif, akan mempengaruhi tingkat keyakinan siswa terhadap potensi yang dimiliki (self efficacy) dan pada akhirnya mempengaruhi strategi siswa dalam belajar, seperti yang dapat dilihat dalam fase self regulated learning (Zimmerman, 2000). Selain itu salah satu materi yaitu
SMART goal (pada pelatihan regulasi diri) dan river of life (pelatihan konsep diri) merupakan materi yang menuntut siswa untuk dapat menentukan tujuan dalam hidupnya, meskipun pada SMART goal siswa dituntut untuk dapat membuat tujuan yang lebih spesifik dan terukur serta terbagi berdasar kurun waktu tertentu. Kemampuan siswa dalam menentukan tujuan berkorelasi positif terhadap pencapaian prestasi akademik yang merupakan salah satu indikator daya saing (Diseth, 2011). Kedua, adanya dukungan guru baik di kelompok eksperimen maupun kelompok kontrol. Reward dan punishment yang diberikan guru menyebabkan guru dipersepsikan positif dan mempengaruhi motivasi intrinsik siswa dalam belajar sehingga pada akhirnya siswa meregulasi dirinya dalam belajar (Rosianti, 2013).

Daya saing siswa sangat diperngaruhi kepercayaan diri mereka terhadap potensi yang dimiliki. Kesulitan siswa dalam menyerap informasi yang disampaikan berhubungan secara langsung dengan kepercayaan diri siswa yang rendah. (Aronson, 2002; Cheng \& Ickes, 2009). Oleh karena itu selama intervensi, afirmasi yang positif terhadap potensi dan keadaan yang dihadapi terus-menerus disampaikan, sehingga siswa bersedia untuk lebih terlibat dalam proses belajar dan memandang pengalaman hidupnya secara positif (Hofer, Busch, \& Kartner, 2011).

Selain manfaat yang telah disampaikan sebelumnya, penelitian ini tidak terlepas dari keterbatasan. Penelitian ini mengambil siswa SMK baik yang beresiko maupun tidak, sehingga modul ini tidak dapat digeneralisasikan untuk tingkat pendidikan lainnya, seperti pendidikan dasar maupun perguruan tinggi. Oleh karena itu perlu dilakukan modifikasi ketika penelitian sejenis akan dikenakan 
pada siswa dengan latar belakang tingkat pendidikan yang berbeda.

\section{Saran}

Saran dari penelitian ini ditujukan bagi siswa, sekolah, dan guru serta peneliti selanjutnya.

Bagi siswa diharapkan dapat mencoba untuk menerapkan materi-materi yang telah disampaikan dalam pelatihan ini, mulai dari mengenali potensi diri, menetapkan tujuan belajar, mengelola waktu, mengelola emosi, dan mengelola lingkungan belajar. Selain itu, diharapkan siswa dapat memanfaatkan fasilitas yang disediakan oleh sekolah seperti perpustakaan, layanan Bimbingan Konseling untuk mendukung strategi belajar yang dilakukan. Kemudian, siswa diharapkan berupaya meminimalisir perilaku-perilaku yang tidak memberi kontribusi positif terhadap pencapaian prestasi seperti tidak mendengarkan guru di kelas, membolos, dan tidak belajar secara rutin dengan menanamkan kesadaran pada diri bahwa siswa harus bertanggung jawab terhadap waktu tiga tahun yang mereka tempuh di SMK yang akan menentukan keberhasilan kelak setelah lulus.

Bagi sekolah, diharapkan mengupayakan lingkungan belajar yang lebih kondusif bagi siswa untuk belajar dan memberikan pembekalan kepada siswa yang sifatnya soft skill, salah satunya seperti pelatihan regulasi diri, yang dilakukan secara rutin, sehingga siswa tidak hanya mempelajari materi tetapi juga memperbaiki sikap mereka dalam belajar.

Bagi guru, diharapkan senantiasa memberikan sikap yang terbuka terhadap masukan, saran, dan pendapat yang disampaikan oleh siswa, sehingga siswa merasa bahwa ada upaya yang dilakukan secara sinergis antara guru dan siswa untuk melakukan beberapa perubahan. Selain itu, guru diharapkan meningkatkan metode mengajar yang dijalankan, sehingga kelas menjadi lebih atraktif dan interaktif dan siswa menjadi lebih bersemangat dalam belajar.

Peneliti selanjutnya diharapkan dapat memperluas kancah penelitian, tidak hanya di sekolah kejuruan dengan siswa beresiko, melainkan juga ke sekolah umum ataupun jenjang pendidikan yang lain dan memiliki posisi tawar yang lebih tinggi kepada pihak sekolah dengan meminta waktu pelaksanaan pelatihan yang lebih fleksibel, sehingga penyampaian materi tidak terburu-buru dan dapat mendalam.

\section{Ucapan Terimakasih}

Terima kasih disampaikan kepada pihak-pihak yang telah mendukung terlaksananya penelitian ini, yaitu, Ditlitabmas Dikti yang telah menyediakan dukungan dana, pihak-pihak sekolah yang bersedia bekerja sama, Fakultas Psikologi UNDIP yang telah memberikan fasilitas untuk diskusi, dan para mahasiswa yang membantu kelancaran dalam pelaksanaan penelitian ini.

\section{Kepustakaan}

Aronson, J. (2002). Improving academic performance, impact of psychological factors on education. San Diego: Academic Press.

Baron, P. A., \& Byrne, D.( 1991). Social psychology: Understanding human interaction. New York: Allyn and Bacon Inc.

Bernadin, H. J., \& Russel, J. E. A. (1998). Human resource management: An experimental approach. $\left(2^{\text {nd }} \mathrm{ed}\right.$ ). Singapore: McGraw-Hill Company. 
Boekaerts, M. (1999). Self regulated learning: Where we are today. International Journal of Educational Research, 31, 445457.

Boekaerts, M., \& Niemivirta, M. (2000). Self regulated learning: Finding a balance between learning goals and ego protective goals. Dalam M. Boekaerts, P. R. Pintrich, \& M. Zeidner (Eds.), Handbook of self regulation (hal. 417450). San Diego: Academic Press.

Boekaerts, M. (2010). The crucial role of motivation and emotion in classroom learning. Dalam H. Dumont, D. Istance, \& F. Benavides. The nature of learning: Using research to inspire practice (91-111). OECD.

Bong, M. (2008). Effect of parent-child relationships and classroom goal structures on motivation, help seeking avoidance, and cheating. The journal of experimental education, 76(2), 191-217.

Brehn, S.S ., \& Kassin, M. S. (1990). Social psychology. London: Houghtown Mifflin Company.

Cheng, W., \& Ickes, W. (2009). Conscientiousness and self motivation as mutually compensatory predictors of university level GPA. Personality and individual differences, 47, 817-822.

Chickering, A. W., \& Reisser, L. (1993). Education and identity. $2^{\text {nd }} \mathrm{ed}$. San Fransisco: Jossey-Bass, Inc.

Chickering, A. W., \& Schlossberg, N. K. (1995). Getting the most out of college. $2^{\text {nd }}$ ed. New Jersey: Prentice Hall.

Diseth, A. (2011). Self efficacy, goal orientations and learning strategies as mediators between preceding and subsequent academic achievement. Learning and Individual Differences, 21, 191-195.

Hendriyani \& Guntarto, B. (2011). Defining media literacy in Indonesia. Paper presented at the International Association of Media Communication Research, Istanbul, Turki.

Hofer, J., Busch, H., \& Kartner, J. (2011). Self-regulation and well-being: The influence of identity and motives. European Journal of Personality, 25, 211224, doi: 10.1002/per.789.

Houston, J. M., McIntire, S. A., Kinnie, J., \& Terry, C. (2002). A Factorial Analysis of Scales Measuring Competitiveness. Journal of Educational and Psychological Measurement, 62(2), 284-298.

Labuhn, A. S., Zimmerman, B. J., \& Hasselhorn, M. (2010). Enhancing students' selfregulation and mathematics performance: The influence of feedback and self evaluative standards. Metacognition and Learning, 5(2), 173-194.

Montalvo, F. T., \& Torres, M. C. G. (2004). Self regulated learning: Current and future direction. Electronic Journal of Research in Educational Psychology, 2(1), 1-34.

Panadero, E., Tapia, J. A., \& Huertas, J. A. (2012). Rubrics and self-assessment scripts effects on self-regulation, learning, and self-efficacy in secondary education. Learning and Individual Differences, 22, 806-813.

Park, Y. S., \& Kim, U. (2006). Family, parent-child relationship, and academic achievement in Korea. Indigenous and cultural psychology, understanding people in context. New York: Springer.

Printich, P. R. (2000). The role of goal orientation in self regulated learning. Dalam M. Boekaerts, P. R. Pintrich, \& M. Zeidner (Eds.), Handbook of self regulation (hal. 451-502). San Diego: Academic Press.

Rakes, G. C. (2010). The impact of online graduate students' motivation and self regulation on academic procrastination. Journal of Interactive Online Learning, 9(1), 78-93. 
Rosianti, R. (2013). Hubungan antara persepsi terhadap atraksi interpersonal guru dengan motivasi berprestasi pada siswa kelas XI di SMA Negeri 9 Semarang. (Naskah tidak dipublikasikan), Fakultas Psikologi, Universitas Diponegoro, Semarang.

Sawitri, D. R., \& Ariati, J. (2010). Malas, ngantuk, dan bosan: Hambatan Mahasiswa untuk mencapai Indeks Prestasi Tinggi. Paper presented in Konferensi Nasional Asosiasi Psikologi Pendidikan Indonesia, Malang.

Sawitri, D. R., \& Ariati, J. (2011). Self regulation training as an effort to enhance students' competitiveness. Paper presented in The International Conference on Psychology of Resilience, Jakarta.

Schunk, D. H., \& Ertmer, P. A. (2000). Selfregulation and academic learning: Self-efficacy enhancing

interventions. Dalam M. Boekaerts, P. R. Pintrich, \& M. Zeidner (Eds.), Handbook of self-regulation (hal. 631-649). San Diego: Academic Press.

Soric, I., \& Palekcic, M. (2009). The role of student interests in self regulated learning: the relationship between student interests, learning strategies, and causal attributions. European Journal of Psychology of Education, 24(4), 545-565.
Vandevelde, S., Van Keer, H., \& De Wever, B. (2011). Exploring the impact of student tutoring on at-risk fifth and sixth graders'self-regulated learning. Learning and Individual Differences, 21, 419-425.

Wolters, C. A. (2003). Understanding procrastination from a self regulated learning perspective. Journal of Educational Psychology, 95(1), 179-187.

Woolfolk, A. (2009). Educational psychology. New Jersey: Pearson Education.

http://suaragratiafm.wordpress.com/2013/ 07/19/kpi-masyarakat-membutuhkanlembaga-penyiaran-yang-edukatif/

Zimmerman, B. J. (2000). Attaining self regulation: a social cognitive perspective. Dalam M. Boekaerts, P. R. Pintrich, \& M. Zeidner (Eds.), Handbook of self regulation (hal. 13-39). San Diego: Academic Press.

Zimmerman, B. J. (2001). Theories of self regulated learning and academic achievement: An overview and analysis. Self regulated learning and academic achievement: Theoretical perspective. New Jersey: Lawrence Erlbaum Associates.

Zimmerman, B.J. (2002). Becoming a self regulated learner: An overview. Theory into Practice, 41, 64-70. 